\title{
Development of a Pressure Control System According to Paste Rheology for Ultrasound Processing in Industrial Olive Oil Extraction
}

\author{
Antonia Tamborrino $^{1} \cdot$ Roberto Romaniello $^{2} \cdot$ Claudio Perone $^{2}\left(\mathbb{0} \cdot\right.$ Hazar Moujahed $^{2} \cdot$ Alessandro Leone $^{1}$
}

Received: 22 March 2021 / Accepted: 7 June 2021 / Published online: 23 July 2021

(c) The Author(s) 2021

\begin{abstract}
Recent research has demonstrated how ultrasound can benefit the industrial processing of olive paste before oil extraction. However, the absence of a device for controlling pressure inside the sonication cell is a major hindrance to its application. To address this problem, a pneumatic device with a programmable logic controller was implemented to automatically adjust pressure in the sonication cell according to a preset value: its functionality was tested in industrial oil extraction. An experiment was conducted to compare device performance when applied to olive batches with different solid/liquid ratios and differing rheology. The control system adjusted the flow section of the valve at the outlet of the sonication cell and the mass flow rate of the feed pump in order to maintain the pressure preset by the operator. Results indicate that the pressure was $3.0 \pm 0.2 \mathrm{bar}, 3.5 \pm 0.2 \mathrm{bar}$, and $4.0 \pm 0.2$ bar when the set point was $3.0 \mathrm{bar}, 3.5 \mathrm{bar}$, and 4.0 bar, respectively: there was thus no significant difference between controlled and set values. This indicates that the device is able to control pressure inside the sonication cell with a maximum deviation of $0.2 \mathrm{bar}$. In this case, the sonication intensity was stabilized at $135 \mathrm{~W} / \mathrm{cm}^{2}$, $150 \mathrm{~W} / \mathrm{cm}^{2}$, and $165 \mathrm{~W} / \mathrm{cm}^{2}$ at $3.0 \mathrm{bar}, 3.5 \mathrm{bar}$, and $4.0 \mathrm{bar}$, respectively. This study presents an advancement in ultrasound applications for industrial olive oil extraction: optimal pressure control in the sonication cell.
\end{abstract}

Keywords Ultrasound · Process control · Viscosity $\cdot$ Pneumatic device $\cdot$ Pressure

\section{Introduction}

High-intensity ultrasound at a frequency $\geq 20 \mathrm{kHz}$ generates acoustic cavitation. In an acoustic field, microbubbles in solution may grow by rectified diffusion and by

Claudio Perone

claudio.perone@unifg.it

Antonia Tamborrino

antonia.tamborrino@uniba.it

Roberto Romaniello

roberto.romaniello@unifg.it

Hazar Moujahed

hazarmjahed17@gmail.com

Alessandro Leone

alessandro.leone@uniba.it

1 Department of Agricultural and Environmental Science, University of Bari Aldo Moro, Via Amendola 165/A 70126, Bari, Italy

2 Department of the Sciences of Agriculture, Food Natural resources and Engineering, University of Foggia, Via Napoli, $25-71100$, Foggia, Italy bubble-bubble coalescence (Ciawi et al., 2006). Cavitation bubbles reach a maximum size and then collapse violently, generating mechanical, physical, and chemical effects such as shockwaves and turbulence (Ashokkumar et al., 2007) powerful enough to break inter- and intra-molecular bonds. Although ultrasound as a technology has yet to find widespread acceptance in the olive oil extraction industry, several laboratory and industrial-scale studies have shown promising applications.

Interest in the use of ultrasound (US) to extract various classes of bioactive molecules from agro-industrial products and by-products keeps growing (Kia et al., 2018; Kumari et al., 2018; Osete-Alcaraz et al., 2019).

The first study on the application of high-intensity ultrasound in the virgin olive oil extraction process was carried out at laboratory-scale processing plants by Jiménez et al. (2007). Ultrasound pre-treatment of the olive paste improved oil extractability. More recently, Bejaoui et al. (2016a, b) conducted a laboratory study to determine the effects of high-intensity ultrasound pretreatment of olive paste on the quality of the oil. A number of others studies have investigated the effects of ultrasonic treatment on 
the quality of industrial virgin olive oil (VOO) extraction (Almeida et al., 2017; Leone et al., 2018; Romaniello et al., 2019; Tamborrino et al., 2019). Iqdiam et al. (2018) studied the influence of high-power ultrasound (HPU) on the malaxation time, olive oil yield efficiency, and final product quality. They found that the malaxation time could be reduced by $10 \mathrm{~min}$ and that the extraction yield increased by $1 \%$. Increasing the HPU treatment time led to a significant increase in total tocopherol and pigments. Bejaoui et al. $(2017,2018)$ investigated the effects of three high-power ultrasound frequencies on oil yield and VOO characteristics in a semi-industrial scale plant. Taticchi et al. (2019) introduced a high-power ultrasound device in an industrial scale plant. Results showed that the extraction yield and phenol content of oil extracted after ultrasound treatment of the olive paste were better than those of oil extracted from olives at an early stage of ripening using traditional methods. No significant effects on the legal and commercial parameters of VOO were found for olives at the mediumearly ripening stage.

Although a number of studies have analyzed the effects of ultrasound treatment on the characteristics of olive oil and the extraction yield, few have focused on the functionality of the US machine. As demonstrated in many scientific papers, the effects of ultrasound on biological matrices can be enhanced by applying pressure (Chemat et al., 2011; Mantas et al., 2000). Although manosonication (MS) is primarily used for microorganism inactivation (Guzel et al., 2014), recent studies have investigated its possible application to enhance bioactive compound extraction (Tchabo et al., 2017). However, research should focus on the optimization and standardization of US in each specific application for industrial uptake (Kumari et al., 2018).

As for the olive oil extraction process, Servili et al. (2019) recently highlighted that the pressure level generated in the US cell is a parameter strongly affecting US treatment. These authors evaluated the application of low-frequency ultrasound during industrial-scale olive oil extraction under different pressures (1.7 bar and 3.5 bar); extractability increased when the olive paste was processed at 3.5 bar. However, when the pressure in the sonication cell increases, additional power from the US generator is required to maintain adequate cavitation activity. Although increasing the US machine size could be a solution, it would be more expensive in terms of both initial and operating costs. In addition, the higher pressures would be an additional safety concern. Findings indicate that the main quality parameters were not affected and that there was a positive impact on the phenolic composition of VOO, but only when the system is operated at 3.5 bar. This therefore confirms the importance of appropriate pressure control in the sonication cell to improve the performance of the ultrasonic treatment, and thus enhance the release of the intracellular content of processed olives.
For a set feed pump mass flow rate, the pressure level in the sonication cell is strongly influenced by the characteristics of the olive paste, i.e., its solid/liquid ratio, which affects its rheology (Boncinelli et al., 2013; Tamborrino et al., 2014). The viscosity of the processed olive paste depends on the raw material and is influenced not only by its concentration but also by the solid particle size, stiffness, composition, and elastic properties (Di Renzo \& Colelli, 1997). These parameters can vary considerably according to olive variety, pedo-climatic conditions, ripening index (Migliorini et al., 2011; Nergiz \& Engez, 2000), and the processing technology adopted upstream of the ultrasound treatment device (Leone et al., 2015; Sadkaoui et al., 2017). As olive pastes entering the sonication can vary considerably in rheology, it can be very difficult to control US treatment in industrial oil mills during processing. Continuous automatic control of the operating pressure in the flow cell is therefore essential for effective US treatment of olive pastes.

Since manosonication seems to improve the extraction process, it is essential to insert an appropriate control device to adjust pressure in the sonication cell. There is little or no literature available on manosonication for olive paste conditioning. At present, there are no studies on the design, construction, and testing of devices capable of monitoring and adjusting the operating pressure within the sonication cell for the ultrasound treatment of olive pastes. Given the interest in applying this technology to olive oil production, research should focus on optimizing sonication by adjusting process parameters such as pressure.

Servo pneumatic systems combined with a pneumatic proportional valve may serve this purpose. The pressure control system (PCS) is an important component used to control both the pressure and mass flow rate of the paste (Saravanakumar et al., 2017). As reported in Beater (2010), a servo pneumatic system combined with pneumatic actuators has numerous advantages, such as cleanliness, low cost, high power-toweight ratio, easy maintenance, safety, and long working life.

This study tested a new PCS system equipped with electronic technologies to maintain a constant pressure within the sonication cell. Research also aimed to understand the functional application of the pneumatic system in an industrial olive oil extraction plant in order to evaluate its ability to adjust the pressure into the sonication cell as the rheology of olive pastes varies.

\section{Materials and Methods}

This study adopted a step-by-step procedure to analyze and optimize a PCS and enhance the performance of an industrial ultrasonic processor for the continuous operation of low-frequency, high-power US in an industrial olive oil mill. The research methodology can be summarized as follows: 
1. Study of the relationship between the solid/liquid ratio and the rheological behavior of olive paste

2. Theoretical evaluation of paste flow behavior considering the rheological parameter assessed in step 1

3. Optimization of the pressure control system (PCS) to manage pastes with different rheological behavior (automatic control of the operating pressure in the ultrasonic cell)

4. Final functional tests during US system operation in an industrial olive mill

\section{Industrial Olive Oil Equipment Plant Integrated with IUP}

Tests were carried out in an industrial olive oil mill located in Puglia (Pietro Leone\&Figli, s.n.c., Puglia, Italy). The olive oil extraction plant consists of a defoliator, a washing machine, a hammer crusher (mod. Hammer Mill Crusher; Alfa Laval Corporate AB, Lund, Sweden) with grid hole of $7 \mathrm{~mm}$, a total destoner (mod. destoner; Alfa Laval Corporate AB, Lund, Sweden), a group of six malaxer machines, a 3-phase decanter (mod. NX X32; Alfa Laval Corporate $\mathrm{AB}$ ), and one vertical plate centrifuge (mod. UVPX 510; Alfa Laval Corporate AB).

\section{Industrial Ultrasound Processor with Standard Equipment (IUP-SE)}

The industrial ultrasonic processor employed for experimental testing was manufactured by Hielscher Gmbh (Teltow, Germany) and installed by Seneco Science (Seneco s.r.l., Milano, Italy). It comprised a $4 \mathrm{~kW}$ power supply, an ultrasound generator working at $20 \mathrm{kHz}$, and an ultrasound probe (mod. CS4d40L4 Cascatrode ${ }^{\mathrm{TM}}$, Hielscher Gmbh). All functions were controlled by a PLC equipped with a touch screen through which it was possible to set the amplitude value to between 0 and $100 \%$, corresponding to $30-59 \mu \mathrm{m}$. The Cascatrode $^{\mathrm{TM}}$ was placed in a vertical stainless-steel tube (cell). Olive paste flowed into the cell from the bottom and exited from the top. A pressure probe was installed on the output section of the flow cell to monitor and record olive paste pressure at a frequency of $1 \mathrm{~Hz}$. All parameters (electric power, pressure, amplitude, and pulsation frequency) were shown in real time on the PLC display. Taking into account the chosen frequency and amplitude parameters, the system was able to automatically modulate the electric power as a function of the pressure detected in the US cell. The operating parameters were recorded with a 1-s sampling interval on an SD card installed in the PLC for the entire duration of the test (about $16 \mathrm{~min}$, the loading time of the malaxer machine) and were visible in real-time on the PLC display.

The IUP-SE was installed between the crusher and the malaxer through DN 90 connections.
Industrial Ultrasound Processor with a Pressure Control System (IUP-PCS) and Working Principle

The IUP-PCS (Fig. 1) has the same basic configuration as the IUP-SE, but with the important addition of an accurate pressure control system. A pneumatic operated pinch valve was installed downstream of the US machine, just after the treatment cell. The compressed air entering the casing of the valve throttles the sleeve, causing a reduction in product flow rate and an increase in pressure upstream of the valve. Pressure control was achieved through a PID controller (Nanodac ${ }^{\text {TM }}$ Recorder/Controller), which receives input from a pressure transducer (ceramic pressure transmitter flush diaphragm; $0.5 \%$ accuracy, with an output $0-6$ bar in 4-20 mA). The output signal of the controller (4-20 mA) served as a double control. The first to adjust the throttling of the valve by means of a pressure reducer, which receives compressed air from a compressor, followed by an I/P converter which regulates the air pressure supplied to the pinch valve. The second, when the only valve adjustment is not sufficient, to control the number of revolutions of the cavity pump and thus the flow rate of the product. The PCS is also a safety device: the cavity pump switches off for safety when the impelling head of the pump exceeds 6 bar.

\section{Experimental Design and Processing Conditions}

In order to investigate the operational functionality of the industrial ultrasonic processor and pressure level maintenance as a function of the characteristics of the inlet olive paste, experimental tests were carried out on four homogeneous lots of the olive cultivars Coratina, Peranzana, Cima di Bitonto, and Leccino (Olea europaea L).

The olives were mechanically harvested in November 2020 and then processed in an industrial oil mill using two different machines for olive paste preparation, as indicated below:

- Lot OP1, olives of the Coratina cultivar processed using a destoner machine

- Lot OP2, olives of the Peranzana cultivar processed using a hammer crusher

- Lot OP3, olives of the Cima di Bitonto cultivar processed using a hammer crusher

- Lot OP4, olives of the Leccino cultivar processed using a hammer crusher

Table 1 reports the olive paste composition and solid/ liquid ratio for each lot, as the mean value of 10 olive samplings.

The data shows four lots of olives with differing composition and a solid/liquid ratio between 0.18 and 0.47 . Experimental testing was conducted in the industrial olive 


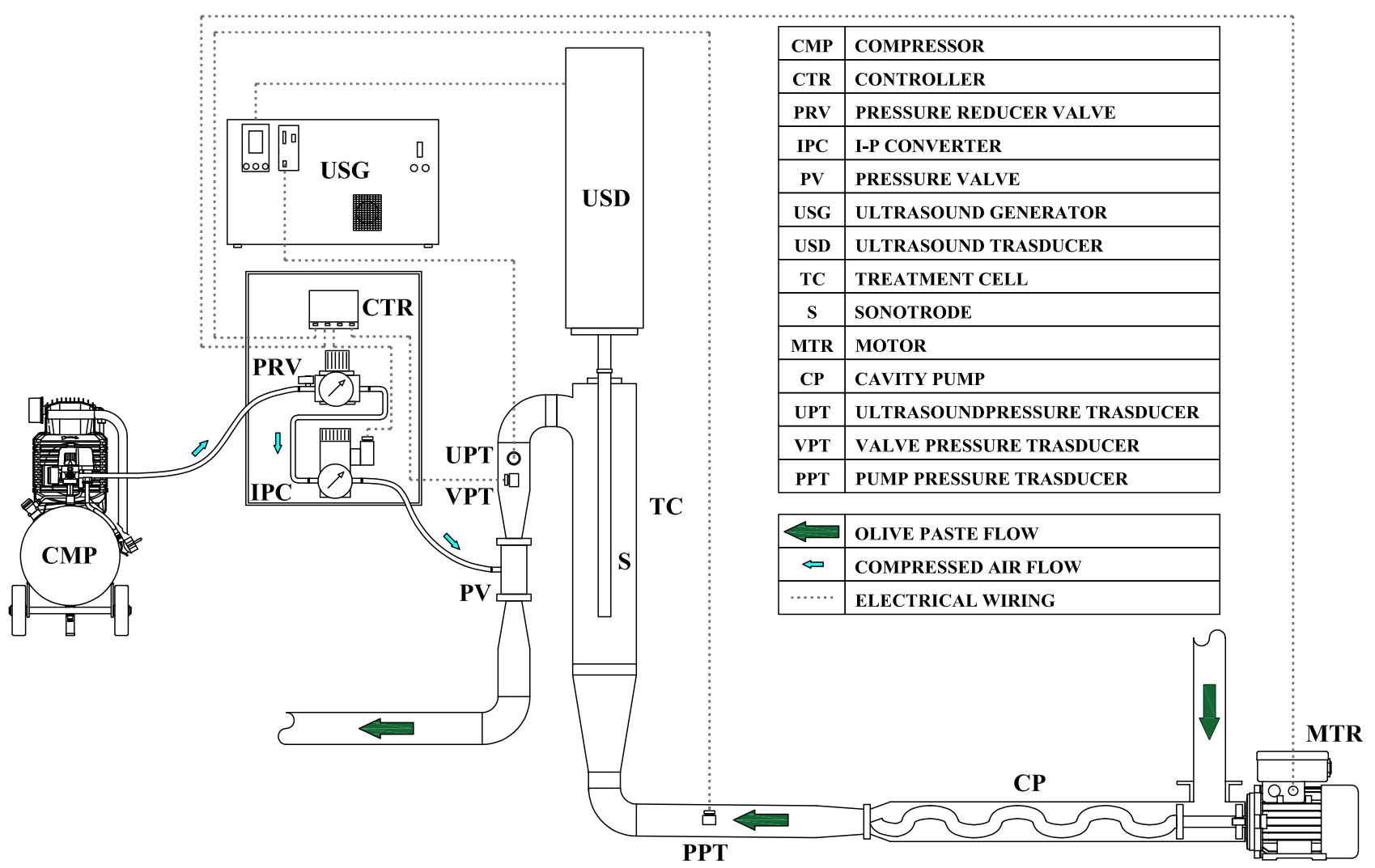

Fig. 1 The main components of the industrial ultrasound processor with pressure control system (IUP-PCS)

mill described above using the IUP. The ultrasonic processor had two different configurations during testing: (a) industrial ultrasound processor with standard equipment (IUP-SE); (b) industrial ultrasound processor with an implemented pressure control system (IUP-PCS).

Each homogeneous lot of olives was divided into 36 sub-lots weighing $700 \mathrm{~kg}$ each. For each homogeneous lot of olives, 9 sub-lots were used for the IUP-SE tests, and 9 sub-lots for the IUP-PCS tests at three different preset pressure values (3.0 bar, 3.5 bar and $4.0 \mathrm{bar}$ ) and three paste flow rates $(1000 \mathrm{~kg} / \mathrm{h}, 2000 \mathrm{~kg} / \mathrm{h}$, and $3000 \mathrm{~kg} / \mathrm{h})$. Each test was replicated three times. The dilution water at decanter centrifuge was $350 \mathrm{l} / \mathrm{h}$. Malaxation was performed for $30^{\prime}$ at $26 \pm 1{ }^{\circ} \mathrm{C}$.

A schematic description of the experimental plan is shown in Table 2.
The viscosity of each lot was assessed by means of the consistency index $(\mathrm{K})$ and flow behavior index of the inlet olive paste. Pressure values in the flow cell and at the impeller head were recorded continuously while the olive paste passed from the crusher to the malaxer machine.

\section{Olive Paste Characterization}

Moisture content and oil content in the olive paste (\% w/w) were determined by drying the olive paste sampled at $105^{\circ} \mathrm{C}$ to a constant weight; the total oil content was determined following the analytical technique described in Cherubini et al. (2009). Solids were calculated as the difference between $100 \%$ and the sum of the percentages of liquids.
Table 1 Olive paste physical characteristics

\begin{tabular}{lllll}
\hline Lots of olives & Water content $(\%)$ & Oil content $(\%)$ & Solids content $(\%)$ & Solid/liquid ratio $(\%)$ \\
\hline OP1 & $65.17 \pm 0.33 \mathrm{a}$ & $22.80 \pm 0.15 \mathrm{a}$ & $12.03 \pm 0.22 \mathrm{a}$ & $0.18 \pm 0.03 \mathrm{a}$ \\
OP2 & $62.10 \pm 0.29 \mathrm{~b}$ & $19.30 \pm 0.11 \mathrm{~b}$ & $18.60 \pm 0.37 \mathrm{~b}$ & $0.23 \pm 0.01 \mathrm{~b}$ \\
OP3 & $55.25 \pm 0.24 \mathrm{c}$ & $18.54 \pm 0.17 \mathrm{c}$ & $26.21 \pm 0.13 \mathrm{c}$ & $0.36 \pm 0.06 \mathrm{c}$ \\
OP4 & $51.22 \pm 0.27 \mathrm{~d}$ & $16.71 \pm 0.21 \mathrm{~d}$ & $32.07 \pm 0.11 \mathrm{~d}$ & $0.47 \pm 0.04 \mathrm{~d}$ \\
\hline
\end{tabular}

Different letters denote statistically significant differences ( $p<0.05$, Tuckey's test) 
Table 2 Schematic description of the experimental plan

\begin{tabular}{lllll}
\hline Lot & Test equipment & Pressure in sonication cell & Paste flow rate & Measurements of pressure \\
\hline OP1 & IUP-SE & Imposed by the system & $1000 \mathrm{~kg} / \mathrm{h}$ & $\begin{array}{l}\text { Pump impeller head } \\
\text { Sonication cell }\end{array}$ \\
OP2 & & $3000 \mathrm{~kg} / \mathrm{h}$ & \\
OP3 & & & \\
OP4 & & & $1000 \mathrm{~kg} / \mathrm{h}$ & Pump impeller head \\
OP1 & IUP-PCS & $3.0 \mathrm{bar}$ & $2000 \mathrm{~kg} / \mathrm{h}$ & Sonication cell \\
OP2 & & $3.5 \mathrm{bar}$ & $3000 \mathrm{~kg} / \mathrm{h}$ & \\
OP3 & & $4.0 \mathrm{bar}$ & & \\
OP4 & & & \\
\hline
\end{tabular}

\section{Rheological Characteristics}

A Brookfield rotational viscometer (Brookfield Engineering Laboratories, Inc., Stoughton, MA, USA) equipped with interchangeable disc spindles, 2-7 (model RV/HA/ HB; Brookfield DVII + Brookfield Engineering Laboratories), was used for the rheological analysis of olive paste samples. Viscosity was measured using $600 \mathrm{~mL}$ of olive paste. For each run, three replicate olive paste samples were collected at the crusher outlet and placed into 1000$\mathrm{mL}$ glass containers conditioned at $27^{\circ} \mathrm{C}$ in a thermostatic bath. The apparent viscosity of each sample was recorded at 10 rotational speeds from 0.5 to $100 \mathrm{rpm}$ using the RV/ HA/HB-4 spindle. To interpret the experimental results in terms of viscosity, the torque-speed data and scale readings were converted to shear stress and shear rate using numerical conversion values. An empirical power-law model was used to calculate the apparent viscosity and flow behavior index from the shear rate, using the power law equation:

$\eta_{\text {app }}=K \dot{\gamma}^{n-1}$ where $\eta_{a p p}$ is the apparent viscosity, $\dot{\gamma}$ is the shear rate $\left(\mathrm{s}^{-1}\right)$, $n$ is the flow behavior index (without size), and $K$ is the consistency index $\left(\mathrm{Pa} \mathrm{s}^{n}\right)$. The consistency index coupled with the flow behavior index was used to describe the rheological properties of the olive paste under each condition described in Table 1.

The MATLAB $®$ statistics and machine learning toolbox were used to process the experimental viscosity data. Significance testing was performed using ANOVA and the Tukey-Kramer test for mean separation at $p<0.05$.

\section{Theoretical Evaluation of the Olive Paste Flow Behavior}

The mechanical energy balance of the system was determined to evaluate olive paste flow behavior. Figure 2 shows a schematic representation of the process line between the cavity pump (CP) and the malaxer machine (MM). It consists of a DN90 pipe, 8 large $90^{\circ}$ elbows, and the treatment cell (TC) of the US machine. The valve is represented by a dotted line to show its position once installed. The Bernoulli equation calculated between the exit section of the cavity pump (I) and the exit section of the pipe before the malaxer machine

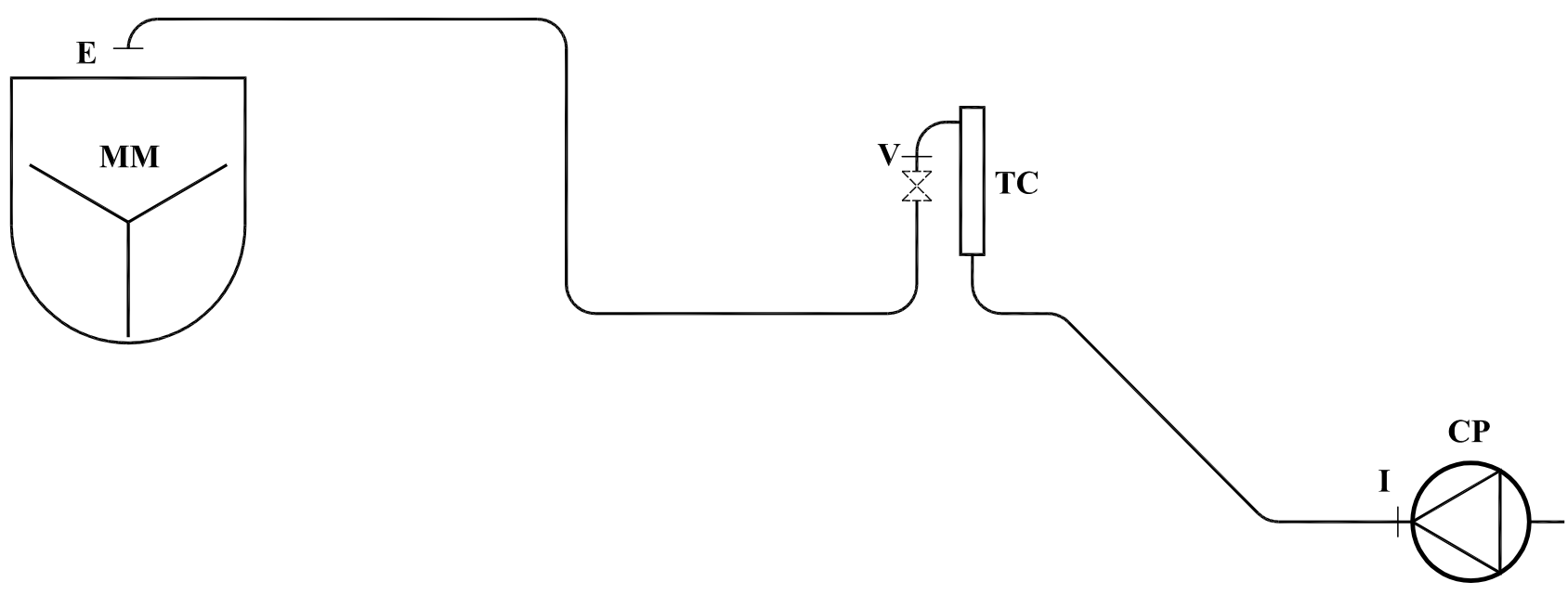

Fig. 2 Schematic representation of the system 
(E) returns the impeller head of the pump. Since the cavity pump is a positive displacement pump, the number of revolutions $(n)$ influences the flow rate only, whereas the pump head is linked to the pressure drop in the system (reasonably assuming that the volumetric efficiency is 1 without stator wear). Once the impeller head is known, the pressure in $\mathrm{V}$ (representative of the pressure inside the TC) can be determined by performing a mechanical energy balance between the pump and the inlet section of the pinch valve $(\mathrm{V})$.

The mechanical energy balance can be calculated as follows:

$\rho g \Delta h+\Delta p+\rho\left(\Delta p_{f p}+\Delta p_{f f}\right)=0$

where $\rho$ is the density of the olive paste; $\Delta h$ is the elevation, considering the plane on which the pump lies as the reference plane; $\Delta p$ is the static pressure between the two considered sections, and $\Delta p_{f p}$ is the pressure drop due to friction losses in the pipes, and $\Delta p_{f f}$ in the fittings. The contribution of kinetic energy is neglected, since the diameter of the pipes is the same in each section. Equation (2) is applied between $\mathrm{I}-\mathrm{E}$ and $\mathrm{I}-\mathrm{V}$, and the mechanical energy of the pump is thus also equal to zero.

The Fanning equation can be used to determine the pressure drop in the pipes:

$\Delta p_{f}=2 f \frac{L}{D} \rho v_{m}^{2}$

where $f$ is the Fanning friction factor, $L$ is the length of the pipes, $D$ the diameter of the pipes, and $v_{m}$ the mean velocity of the paste. The flow behavior of the olive paste is related to the Reynolds number, which in the case of pseudoplastic fluids can be expressed in its general form:

$R e_{G}=\frac{8 \rho v_{m}{ }^{2-n} R^{n}}{K\left[\frac{3 n+1}{n}\right]^{n}}$

and is closely correlated with the rheology of the paste through the consistency index and the flow behavior index. In each case (see "Rheological Characterization"), the flow is laminar, so that the friction factor can be calculated as follows:

$f=\frac{16}{R e_{G}}$

The following expression can be used to estimate the pressure drops in fittings:

$\Delta P_{f f}=k_{f} \rho \frac{v^{2}}{2}$

where $k_{f}$ is the resistance factor, which in the case of very low $R e_{G}$ and $90^{\circ}$ elbows can be estimated using the equation proposed by Steffe et al. (1984):
$k_{f}=191\left(R e_{G}\right)^{-0.896}$

Measuring the pressure drop determined by the pinch valve in a non-Newtonian fluid with laminar flow is no easy task. In this case, it was estimated using the flow coefficient $k_{v}$ provided by the manufacturer and the flow conditions in each specific case.

\section{Results and Discussion}

\section{Rheological Characterization}

Viscosity measurements were carried out to investigate the rheological characteristics of the inlet olive paste. Preliminary experiments aimed to evaluate the consistency of the inlet olive paste. Table 3 reports the determination indexes from the linear regression and the parameters used to characterize the rheology of the olive paste.

Comparison among olive paste samples with different solid/ liquid ratios (OP1, OP2, OP3, and OP4) feeding into the US flow cell reveal significant differences in rheological behavior depending on the consistency index $\mathrm{K}(p<0.05)$, whereas analysis of the flow behavior index $n$ confirms the typical nonNewtonian behavior of the olive paste (Di Renzo \& Colelli, 1997). The coefficient of determination $\left(R^{2}\right)$ is about 0.99 in all these compared. The viscosity parameters show a direct correlation with the solid/liquid ratios reported in Table 1; the increase in the solid/liquid ratio between the theses corresponds to a significant increase in apparent viscosity $(p<0.05)$. The Brookfield viscometer and rheological analysis of the matrix can be used to assess the potential performance of the processing plant (Alexander et al., 2018; Bianchi et al., 2020; Difonzo et al., 2021). Note that the viscosity of the inlet olive paste has been found to vary, and this parameter influences the functionality of the processing machines. The dynamic viscosity of the olive paste strongly affects its flow behavior through the connecting tube and treatment cell (see "Theoretical Evaluation of the Olive Paste Flow Behavior"). The higher the dynamic viscosity, the higher the friction factor and the greater the drop in pressure. In this study, a moderate increase in pressure is desirable to take advantage of manosonication (Meullemiestre

Table 3 Consistency and flow behavior index for olive paste used in the experimental tests

\begin{tabular}{llll}
\hline Thesis & $\mathrm{K}\left(\mathrm{Pa} \mathrm{s}^{n}\right)$ & $n(-)$ & $\left(R^{2}\right)(-)$ \\
\hline OP1 & $167.69 \pm 6.76 \mathrm{c}$ & $0.170 \pm 0.010 \mathrm{~b}$ & 0.997 \\
OP2 & $239.05 \pm 9.83 \mathrm{~b}$ & $0.111 \pm 0.009 \mathrm{~d}$ & 0.997 \\
OP3 & $238.37 \pm 12.49 \mathrm{~b}$ & $0.162 \pm 0.012 \mathrm{c}$ & 0.993 \\
OP4 & $414.45 \pm 16.54 \mathrm{a}$ & $0.179 \pm 0.014 \mathrm{a}$ & 0.989
\end{tabular}

Data are presented as mean and standard deviations of a group of 12 data (three viscosity measurements for four replicates). The different lowercase letters in the rows indicate statistically significant differences among means $(p<0.05)$ 
et al., 2017). However, highly viscous fluids such as olive pastes yield very low Reynolds numbers, indicating laminar flow conditions (Perone et al., 2021), with very small differences in velocity through the cross-section, especially moving toward the center. As a consequence, the shear rate is generally very low, even below $1 \mathrm{~s}^{-1}$ in the middle. The shear thinning behavior of the olive paste means it has a high apparent viscosity, since it increases when the shear rate decreases. As a result, the pressure in the sonication cell could become too high.

\section{Prediction of Flow Behavior and Set Up of the PCS}

Based on "Theoretical Evaluation of the Olive Paste Flow Behavior" and laboratory results on the rheological parameters of samples, it was possible to predict the pressure inside the system. In particular, the aim is to maintain a constant preset pressure value considered optimal for processing and to make sure the pump's pressure head did not exceed the safety value of 6 bar (when the pump must be turned off).

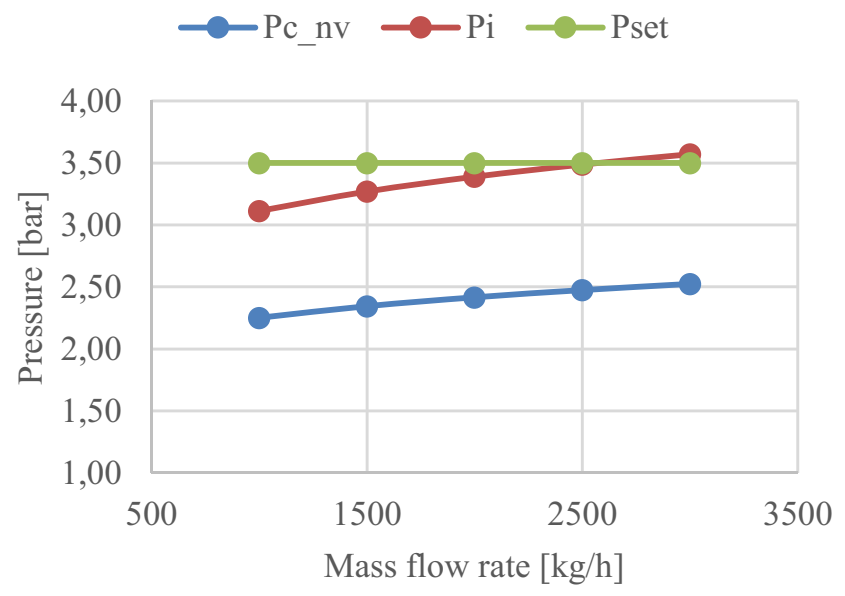

a)

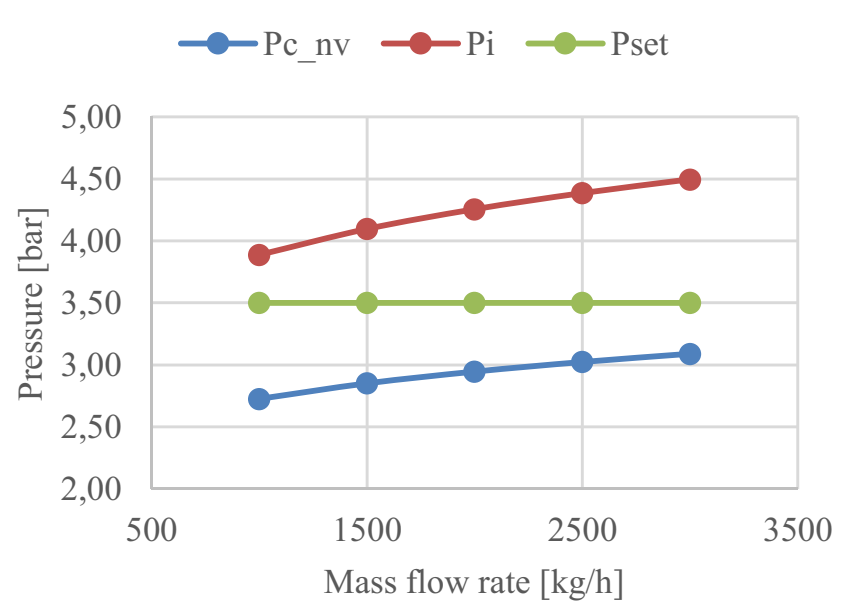

c)
Figure 3 shows the impelling head of the pump and the pressure in TC for each operating condition at different flow rates (typical of the mill in which tests were performed).

For pastes with typical stone concentrations (as in OP2 and OP3), the head of the pump is in the safety range, and the pinch valve should provide a pressure drop equal to the difference between the set point $\left(\mathrm{p}_{\mathrm{set}}\right)$ and the pressure in section $V\left(p_{v}\right)$. Note that $p_{v}$ values in Fig. 3 were calculated with the valve in a fully open position, which due to its configuration generates small pressure drops. Since the cavity pump at a fixed speed supplies a constant flow rate, it is reasonable to assume that the impelling head increases by an amount equal to the pressure drop in the valve. For OP2 and OP3, the impelling head $p_{i}$ increased to about 4.7 bar and 4.9 bar respectively, remaining within the safety range.

When processing OP1, the pump always worked in the safety range, and the PCS should be managed so as to generate the higher squeezing of the sleeve to generate the right

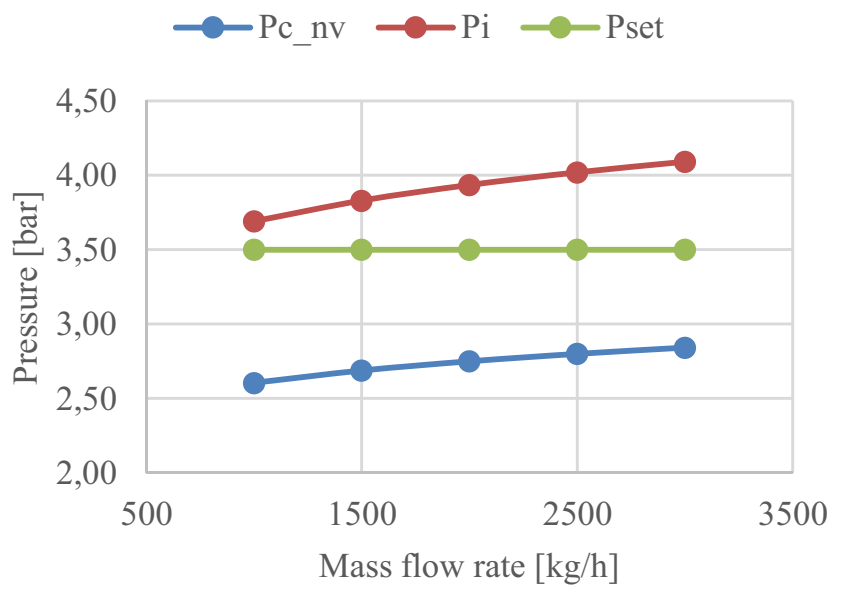

b)

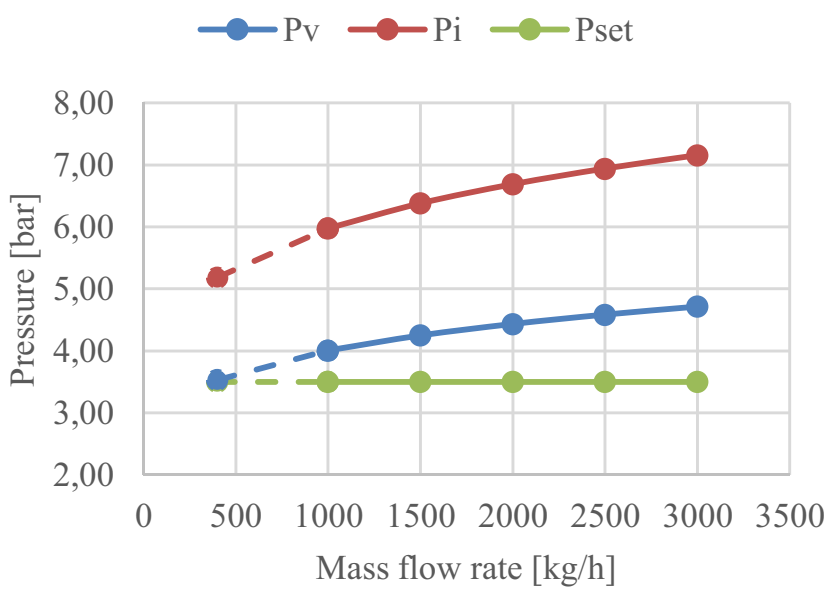

d)

Fig. 3 Theoretical analysis of the pressure inside the system-a OP1, b OP2, c OP3, d OP4 
pressure drop. In the case of OP4, instead, the PCS should fully open the valve and reduce the speed of the pump to achieve a flow rate of about $400 \mathrm{~kg} / \mathrm{h}$ (dotted line in Fig. 3d) so that the $\mathrm{p}_{\text {set }}$ is not exceeded, and the pump is not switched off.

These preliminary considerations provide important insight into how to set the PCS. With the exception of OP4, for which the valve is opened fully, under the other operating conditions, throttling of the valve should be controlled with a stroke in the range $30-80 \%$, with a flow rate that decreases from 3000 to $1000 \mathrm{~kg} / \mathrm{h}$, which is desirable for an equal percentage flow characteristic. In this range, the flow characteristics of the valve are quite linear, enabling appropriate control.

In very extreme conditions such as OP4, the PCS can only reduce the speed of the pump until its lower limit is reached. Other desirable interventions, when possible, include increasing the pipe diameter and reducing the extension of the system.

\section{Experimental Results}

To verify the theoretical results discussed above, the operating pressure values were registered every second when loading each batch of olive paste (OP1, OP2, OP3, and OP4) into the malaxer machine. Table 4 reports the mean value and standard deviation for each operating condition and fully open valve for the following mass flow rates: $1000 \mathrm{~kg} / \mathrm{h}$, $2000 \mathrm{~kg} / \mathrm{h}, 3000 \mathrm{~kg} / \mathrm{h}$. In the case of OP4, the pump was always turned off to avoid damaging its components. In all other cases, the measured pressures were above the theoretically estimated ones. However, the calculated values deviated less than $8.5 \%$ in all cases.

As already predicted by theoretical calculations, experimental results highlighted that using the IUP-SE to process olives with different rheological characteristics leads to significant differences in pressure values; this involves an uncontrolled working of the US machine depending on the rheology of the inlet olive paste. To better understand this behavior, let us consider a paste flow rate of $3000 \mathrm{~kg} / \mathrm{h}$. When batch OP1 was processed using the IUP-SE, the operating pressure reached about $2.64 \pm 0.18$ bar, and the sonotrode provided a power intensity of about $118 \mathrm{~W} /$ $\mathrm{cm}^{2}$ (sonotrode surface area of $41 \mathrm{~cm}^{2}$ ) and an average total power of about $4838 \mathrm{~W}$; when processing batch OP2 in the IUP-SE, the operating pressure reached about $2.96 \pm 0.18 \mathrm{bar}$ and the sonotrode provided a power intensity of about $130 \mathrm{~W} / \mathrm{cm}^{2}$ (sonotrode surface area of $41 \mathrm{~cm}^{2}$ ) and an average total power of about $5330 \mathrm{~W}$. When batch OP3 was processed in the IUP-SE, the operating pressure reached about $3.21 \pm 0.20$ bar and the sonotrode provided a power intensity of about $138 \mathrm{~W} / \mathrm{cm}^{2}$ (sonotrode surface area of $41 \mathrm{~cm}^{2}$ ) and thus an average total power of about $5658 \mathrm{~W}$. Discontinuity in olive paste flow behavior within the cell decreases ultrasound transmission, alters the power and energy transferred to the matrix, and generates ultrasonic reactor malfunctions or blockages (Astráin-Redín et al., 2020; Kar \& Wallrabe, 2020). These results highlight that ultrasound treatment of non-Newtonian olive pastes can induce variations in the operating parameters defining the effect of the acoustic wave; maintenance of the pressure value during ultrasonic treatment is therefore essential for the functioning of these systems. As Servili et al. (2019) indicated an optimal value of 3.5 bar to enhance the cavitation effect and thus the extraction yield, pressure inside the cell should be monitored closely.

Table 5 reports pressure values in $\mathrm{OP} 1, \mathrm{OP} 2$, and $\mathrm{OP} 3$ using an IUP-PCS when the optimal pressure value was set at $3.0 \mathrm{bar}, 3.5 \mathrm{bar}$, and $4.0 \mathrm{bar}$, and when the mass flow rate varied from 1000 to $3000 \mathrm{~kg} / \mathrm{h}$ (as for the fully open valve in Table 4). As predicted, OP4 was blocked by the safety mechanism of the pump.

Note that the $p_{v}$ in each test was almost equal to $p_{\text {set }}$. When a modified apparatus equipped with an automatic pressure control device (PCS) was used, the average pressure remained at the desired value, with a maximum deviation of 0.2 bar in all cases. The sonotrode therefore provided a constant power intensity of about $135 \mathrm{~W} / \mathrm{cm}^{2}$,
Table 4 Pressure values observed during each OP with the valve full opened

\begin{tabular}{|c|c|c|c|c|c|c|}
\hline & \multicolumn{6}{|c|}{ Mass flow rate $(\mathrm{kg} / \mathrm{h})$} \\
\hline & \multicolumn{2}{|l|}{1000} & \multicolumn{2}{|l|}{2000} & \multicolumn{2}{|l|}{3000} \\
\hline & \multicolumn{6}{|l|}{ Pressure (bar) } \\
\hline & $\mathrm{p}_{\mathrm{i}}$ & $\mathrm{p}_{\mathrm{v}}$ & $\mathrm{p}_{\mathrm{i}}$ & $\mathrm{p}_{\mathrm{v}}$ & $\mathrm{p}_{\mathrm{i}}$ & $\mathrm{p}_{\mathrm{v}}$ \\
\hline OP1 & $3.32 \pm 0.18 \mathrm{c}$ & $2.39 \pm 0.21 b$ & $3.57 \pm 0.15 c$ & $2.54 \pm 0.20 b$ & $3.74 \pm 0.13 c$ & $2.64 \pm 0.18 \mathrm{c}$ \\
\hline OP2 & $3.91 \pm 0.15 b$ & $2.76 \pm 0.18 \mathrm{a}$ & $4.14 \pm 0.13 b$ & $2.89 \pm 0.15 \mathrm{a}$ & $4.27 \pm 0.12 b$ & $2.96 \pm 0.18 \mathrm{a}$ \\
\hline OP3 & $4.12 \pm 0.19 \mathrm{a}$ & $2.88 \pm 0.17 \mathrm{a}$ & $4.47 \pm 0.21 \mathrm{a}$ & $3.09 \pm 0.18 \mathrm{a}$ & $4.68 \pm 0.23 a$ & $3.21 \pm 0.20 \mathrm{a}$ \\
\hline OP4 & - & - & - & - & - & - \\
\hline
\end{tabular}

The different lowercase letters in the columns denote statistically significant differences at $p<0.05$ (Tukey's test) 
Table 5 Pressure values observed in OP1, OP2, and OP3 with the valve controlled by the PCS

\begin{tabular}{|c|c|c|c|c|c|c|c|}
\hline & \multirow[b]{4}{*}{$\mathrm{p}_{\text {set }}$} & \multicolumn{6}{|c|}{ Mass flow rate $[\mathrm{kg} / \mathrm{h}]$} \\
\hline & & \multicolumn{2}{|l|}{1000} & \multicolumn{2}{|l|}{2000} & \multicolumn{2}{|l|}{3000} \\
\hline & & \multicolumn{6}{|l|}{ Pressure [bar] } \\
\hline & & $\mathrm{p}_{\mathrm{i}}$ & $\mathrm{p}_{\mathrm{v}}$ & $\mathrm{p}_{\mathrm{i}}$ & $\mathrm{p}_{\mathrm{v}}$ & $\mathrm{p}_{\mathrm{i}}$ & $\mathrm{p}_{\mathrm{v}}$ \\
\hline OP1 & 3.0 & $3.91 \pm 0.12 b$ & $3.01 \pm 0.11 \mathrm{a}$ & $4.02 \pm 0.14 \mathrm{a}$ & $3.02 \pm 0.09 a$ & $4.09 \pm 0.14 \mathrm{a}$ & $3.07 \pm 0.17 \mathrm{a}$ \\
\hline OP2 & & $4.12 \pm 0.11 \mathrm{a}$ & $3.03 \pm 0.18 \mathrm{a}$ & $4.24 \pm 0.13 \mathrm{a}$ & $3.07 \pm 0.16 \mathrm{a}$ & $4.30 \pm 0.11 \mathrm{a}$ & $3.10 \pm 0.18 \mathrm{a}$ \\
\hline OP3 & & $4.23 \pm 0.18 \mathrm{a}$ & $3.09 \pm 0.13 \mathrm{a}$ & $4.37 \pm 0.19 a$ & $3.09 \pm 0.19 a$ & $4.46 \pm 0.19 a$ & $3.15 \pm 0.20 \mathrm{a}$ \\
\hline OP1 & 3.5 & $4.41 \pm 0.12 b$ & $3.47 \pm 0.15 a$ & $4.52 \pm 0.14 \mathrm{a}$ & $3.49 \pm 0.15 a$ & $4.59 \pm 0.12 \mathrm{a}$ & $3.51 \pm 0.16 \mathrm{a}$ \\
\hline OP2 & & $4.65 \pm 0.14 \mathrm{a}$ & $3.51 \pm 0.18 \mathrm{a}$ & $4.74 \pm 0.16 \mathrm{a}$ & $3.55 \pm 0.16 \mathrm{a}$ & $4.79 \pm 0.14 \mathrm{a}$ & $3.56 \pm 0.16 \mathrm{a}$ \\
\hline OP3 & & $4.71 \pm 0.18 \mathrm{a}$ & $3.54 \pm 0.19 a$ & $4.88 \pm 0.20 \mathrm{a}$ & $3.56 \pm 0.18 \mathrm{a}$ & $4.96 \pm 0.19 a$ & $3.58 \pm 0.19 \mathrm{a}$ \\
\hline OP1 & 4.0 & $4.92 \pm 0.17 \mathrm{c}$ & $3.99 \pm 0.11 \mathrm{a}$ & $5.03 \pm 0.12 \mathrm{a}$ & $4.01 \pm 0.17 \mathrm{a}$ & $5.09 \pm 0.12 \mathrm{a}$ & $4.04 \pm 0.16 \mathrm{a}$ \\
\hline OP2 & & $5.13 \pm 0.15 b$ & $4.05 \pm 0.16 \mathrm{a}$ & $5.24 \pm 0.14 \mathrm{a}$ & $4.04 \pm 0.15 \mathrm{a}$ & $5.30 \pm 0.13 \mathrm{a}$ & $4.09 \pm 0.18 \mathrm{a}$ \\
\hline OP3 & & $5.22 \pm 0.19 a$ & $4.11 \pm 0.15 \mathrm{a}$ & $5.38 \pm 0.17 \mathrm{a}$ & $4.13 \pm 0.18 \mathrm{a}$ & $5.44 \pm 0.19 a$ & $4.15 \pm 0.20 \mathrm{a}$ \\
\hline
\end{tabular}

The different lowercase letters in the columns denote statistically significant differences at $p<0.05$ (Tukey's test) and an average total power of about $5535 \mathrm{~W}$ when $\mathrm{p}_{\text {set }}$ was 3.0 bar, a power intensity of about $150 \mathrm{~W} / \mathrm{cm}^{2}$, and an average total power of about $6150 \mathrm{~W}$ when $\mathrm{p}_{\text {set }}$ was $3.5 \mathrm{bar}$, and a power intensity of about $165 \mathrm{~W} / \mathrm{cm}^{2}$ and an average total power of about $6765 \mathrm{~W}$ when $\mathrm{p}_{\text {set }}$ was 4.0 bar. The pneumatic valve therefore controlled the pressure drop. When rheological conditions were those of OP1, compressed air squeezed the sleeve inside the valve to reduce the flow section: this produced an increase in upstream pressure in the range of $0.3-0.6$ bar when $p_{\text {set }}$ was 3.0 bar, of $0.8-1.1$ bar when $\mathrm{p}_{\text {set }}$ was $3.5 \mathrm{bar}$, and of 1.3-1.6 bar when $\mathrm{p}_{\text {set }}$ was 4.0 bar. In the case of OP2, the valve produced a pressure drop of up to 0.3 bar when $p_{\text {set }}$ was 3.0 bar and the mass flow rate was $1000 \mathrm{~kg} / \mathrm{h}$; however, the valve was fully opened at $3000 \mathrm{~kg} / \mathrm{h}$. This confirms that the PCS is able to handle even small variations in pressure. The valve produced a pressure drop in the range of $0.5-0.8$ bar when $p_{\text {set }}$ was 3.5 bar and of 1.0-1.3 bar when $\mathrm{p}_{\text {set }}$ was 4.0 bar. In the case of OP3, with a $\mathrm{p}_{\text {set }}$ of $3.0 \mathrm{bar}$, the initial condition was already close to the desired one, and the valve determined a slight pressure drop of about 0.1 bar when the paste flow rate was $1000 \mathrm{~kg} / \mathrm{h}$. However, at $2000 \mathrm{~kg} / \mathrm{h}$, the valve was fully opened, while at $3000 \mathrm{~kg} / \mathrm{h}$, the $\mathrm{p}_{\text {set }}$ was exceeded, and the PCS reduced the mass flow rate by about $500 \mathrm{~kg} / \mathrm{h}$. When the $\mathrm{p}_{\text {set }}$ was raised to $3.5 \mathrm{bar}$, the valve determined a pressure drop in the range of 0.3-0.6 bar, and at a $\mathrm{p}_{\text {set }}$ of 4.0 bar, the valve supplied a pressure drop in the range of $0.8-1.1$ bar. When the rheological parameters were those of OP4, the valve alone could not adequately control the pressure. In this case, the valve was opened fully and the PCS modulated the speed of the pump, thereby reducing the paste flow rate, although these operating conditions are not ideal for the extraction process.

Results indicate successful real-time pressure control according to the value preset by the operator on the PLC display. Note that the pressure setting and control is critical when ultrasound is used, as reported in many scientific studies. Meullemiestre et al. (2017) used ultrasound treatment for microorganism inactivation, one possible way of enhancing lipid extraction from Rhodosporidium toruloides yeast. The authors ascribed this enhancement to improved cavitation through manosonication, i.e., a combination of ultrasound and pressure. In another study, MS enhanced protein extraction from spirulina, a $6 \%$ improvement with respect to standard ultrasound treatment (Vernès et al., 2019). Tchabo et al. (2017) found that among other non-thermal technologies, MS increased the phenolic compounds in aged mulberry wines. These studies clearly show the positive effects of ultrasound when combined with an optimal pressure value adjusted by means of a suitable valve (manual valve in Meullemiestre et al., 2017; Vernès et al., 2019).

As expected, experimental results indicate that when the pressures within the sonication cell increases, additional power is drawn from the US generator to treat the paste with the same mechanical amplitude. However, increasing the operating pressure excessively introduces several critical issues. Excessively high pressures require the installation of more powerful US machines, with additional initial and operating costs. Furthermore, beyond a certain threshold, a further increase in pressure is not beneficial, probably because the ultrasonic field cannot overcome the combined forces of overpressure and the cohesive force of the liquid molecules (Arroyo \& Lyng, 2017). In addition, in food processing involving flows of liquids or semisolid materials, the control and regulation of pressure is important to safeguard the machinery and connecting pipes, as well as operators. It is therefore important to consider the effects of overpressures, as these can damage the pump when uncontrolled. Moreover, the ultrasonic flow cell is designed to operate 
at pressures of up to 5 bar. The PCS was therefore also designed as a retrofit for the pump to adjust the olive paste mass flow rate, since very viscous pastes could not be handled by simply opening the pinch valve fully. In such cases, the mass flow rate must be reduced. The flow characteristics of the valve allow adequate control over the pressure drop in the system when the stroke is in the range of $20-80 \%$. This means that new strategies should be considered when the valve must work almost in the fully closed or fully open positions. Such strategies require further analysis and experimental testing.

Lastly, the PCS also adjusts the pressure to keep the processing chamber constantly full, thereby avoiding IUP malfunctioning due to the presence of air in the sonication chamber.

\section{Conclusions}

Pressure control within the sonication cell is essential in the industrial application of ultrasound: it maximizes the effect of ultrasound on the plant matrix, avoids sonication device malfunctioning caused by the pressure drop when the flow cell empties, and, lastly, it averts overpressure damage to the plants and pipes.

In this study, a device based on a controlled pressure valve was designed and implemented in an industrial ultrasonic processor for olive paste treatment to keep the pressure inside the sonication cell constant. The ultrasonic processor with a pressure control system (PCS) was installed in an industrial olive mill, and its functionality was analyzed by processing olive pastes with different rheological characteristics.

Results indicate that the pressure adjustment device (PCS) for the ultrasonic processor has a wide range of adaptability and can be used to process olive pastes of differing rheology.

This device will improve the effects of ultrasound applied to industrial oil extraction, also making it easier for the operator to manage the ultrasonic plant.

Nevertheless, the proposed device still needs further study to enhance reliability and adjustment accuracy and to evaluate its use in other food industries employing ultrasound systems. These aspects shall be addressed in future work.

Acknowledgements The authors kindly acknowledge Oleificio Cericola (https://oleificiocericola.com) for granting the permission to use its industrial plant for oil extraction and Seneco Science (www.seneco.it) for providing the industrial ultrasonic equipment used in this research.

Author Contribution Conceptualization, A.T. and A.L.; methodology, C.P. and R.R.; software, C.P. and R.R.; validation, A.T. and A.L.; formal analysis, C.P. R.R. and H.M.; investigation, A.T., R.R. and A.L.; data curation, C.P.; writing - original draft preparation, A.T., C.P. and A.L.; writing-review and editing, A.T., C.P., and A.L.; supervision, A.T. and A.L. All the authors have read and agreed to the published version of the manuscript.
Funding Open access funding provided by Università di Foggia within the CRUI-CARE Agreement.

Data Availability The data presented in this study are available by request from the corresponding author.

\section{Declarations}

Conflict of Interest The authors declare no competing interests.

Open Access This article is licensed under a Creative Commons Attribution 4.0 International License, which permits use, sharing, adaptation, distribution and reproduction in any medium or format, as long as you give appropriate credit to the original author(s) and the source, provide a link to the Creative Commons licence, and indicate if changes were made. The images or other third party material in this article are included in the article's Creative Commons licence, unless indicated otherwise in a credit line to the material. If material is not included in the article's Creative Commons licence and your intended use is not permitted by statutory regulation or exceeds the permitted use, you will need to obtain permission directly from the copyright holder. To view a copy of this licence, visit http://creativecommons.org/licenses/by/4.0/.

\section{References}

Alexander, W. H., Wickson, J., Duncan, J., Carmichael, K., Irvine, D. J., \& Howdle, S. M. (2018). Synthesis and control of crosslinked poly(acrylic acid) based viscosity modifiers using dense phase carbon dioxide as a solvent. Journal of Supercritical Fluids, 139, 38-44. https://doi.org/10.1016/j.supflu.2018.05.003

Almeida, B., Valli, E., Bendini, A., \& Gallina Toschi, T. (2017). Semiindustrial ultrasound-assisted virgin olive oil extraction: Impact on quality. European Journal of Lipid Science and Technology, 119(1). https://doi.org/10.1002/ejlt.201600230

Arroyo, C., \& Lyng, J. G. (2017). The use of ultrasound for the inactivation of microorganisms and enzymes. In Ultrasound in Food Processing (pp. 255-286). John Wiley \& Sons Ltd West Sussex, UK.

Ashokkumar, M., Lee, J., Kentish, S., \& Grieser, F. (2007). Bubbles in an acoustic field: An overview. Ultrasonics Sonochemistry, 14(4), 470-475. https://doi.org/10.1016/j.ultsonch.2006.09.016

Astráin-Redín, L., Ciudad-Hidalgo, S., Raso, J., Condón, S., Cebrián, G., \& Álvarez, I. (2020). Application of High-Power Ultrasound in the Food Industry. In Sonochemical Reactions. IntechOpen. https://doi.org/10.5772/intechopen.90444

Beater, P. (2010). Pneumatic Drives: System Design, Modelling and Control; with... 14 Tables. Springer.

Bejaoui, M. A., Beltran, G., Aguilera, M. P., \& Jimenez, A. (2016a). Continuous conditioning of olive paste by high power ultrasounds: Response surface methodology to predict temperature and its effect on oil yield and virgin olive oil characteristics. $L W T$ - Food Science and Technology, 69, 175-184. https://doi.org/10.1016/j. lwt.2016.01.048

Bejaoui, M. A., Beltrán, G., Sánchez-Ortiz, A., Sánchez, S., \& Jiménez, A. (2016b). Continuous high power ultrasound treatment before malaxation, a laboratory scale approach: Effect on virgin olive oil quality criteria and yield. European Journal of Lipid Science and Technology, 118(2), 332-336. https://doi.org/10.1002/ejlt.201500020

Bejaoui, M. A., Sánchez-Ortiz, A., Aguilera, M. P., Ruiz-Moreno, M. J., Sánchez, S., Jiménez, A., \& Beltrán, G. (2018). High power ultrasound frequency for olive paste conditioning: Effect on the virgin olive oil bioactive compounds and sensorial characteristics. 
Innovative Food Science and Emerging Technologies, 47, 136145. https://doi.org/10.1016/j.ifset.2018.02.002

Bejaoui, M. A., Sánchez-Ortiz, A., Sánchez, S., Jiménez, A., \& Beltrán, G. (2017). The high power ultrasound frequency: Effect on the virgin olive oil yield and quality. Journal of Food Engineering, 207, 10-17. https://doi.org/10.1016/j.jfoodeng.2017.03.013

Bianchi, B., Tamborrino, A., Giametta, F., Squeo, G., Difonzo, G., \& Catalano, P. (2020). Modified rotating reel for malaxer machines: Assessment of rheological characteristics, energy consumption, temperature profile, and virgin olive oil quality. Foods, 9(6), 813. https://doi.org/10.3390/foods9060813

Boncinelli, P., Catalano, P., \& Cini, E. (2013). Olive paste rheological analysis. Transactions of the ASABE, 56(1), 237-243. https://doi.org/10.13031/2013.42574

Chemat, F., Zill-e-Huma, \& Khan, M. K. (2011). Applications of ultrasound in food technology: Processing, preservation and extraction. Ultrasonics Sonochemistry, 18(4), 813-835. https://doi.org/10.1016/j. ultsonch.2010.11.023.

Cherubini, C., Migliorini, M., Mugelli, M., Viti, P., Berti, A., Cini, E., \& Zanoni, B. (2009). Towards a technological ripening index for olive oil fruits. Journal of the Science of Food and Agriculture, 89(4), 671-682. https://doi.org/10.1002/jsfa.3499

Ciawi, E., Rae, J., Ashokkumar, M., \& Grieser, F. (2006). Determination of temperatures within acoustically generated bubbles in aqueous solutions at different ultrasound frequencies. Journal of Physical Chemistry B, 110(27), 13656-13660. https://doi. org/10.1021/jp061441t

Di Renzo, G. C., \& Colelli, G. (1997). Flow behavior of olive paste. Applied Engineering in Agriculture, 13(6), 751-755.

Difonzo, G., Fortunato, S., Tamborrino, A., Squeo, G., Bianchi, B., \& Caponio, F. (2021). Development of a modified malaxer reel: Influence on mechanical characteristic and virgin olive oil quality and composition. $L W T, 135,110290$. https://doi.org/10. 1016/j.lwt.2020.110290

Guzel, B. H., Arroyo, C., Condón, S., Pagán, R., Bayindirli, A., \& Alpas, H. (2014). Inactivation of Listeria monocytogenes and Escherichia coli by Ultrasonic Waves Under Pressure at Nonlethal (Manosonication) and Lethal Temperatures (Manothermosonication) in Acidic Fruit Juices. Food and Bioprocess Technology, 7(6), 1701-1712. https://doi.org/10. 1007/s11947-013-1205-6

Iqdiam, B. M., Mostafa, H., Goodrich-Schneider, R., Baker, G. L., Welt, B., \& Marshall, M. R. (2018). High Power Ultrasound: Impact on Olive Paste Temperature, Malaxation Time, Extraction Efficiency, and Characteristics of Extra Virgin Olive Oil. Food and Bioprocess Technology, 11(3), 634-644. https://doi. org/10.1007/s11947-017-2035-8

Jiménez, A., Beltrán, G., \& Uceda, M. (2007). High-power ultrasound in olive paste pretreatment. Effect on process yield and virgin olive oil characteristics. Ultrasonics Sonochemistry, 14(6), 725731. https://doi.org/10.1016/j.ultsonch.2006.12.006

Kar, B., \& Wallrabe, U. (2020). Performance enhancement of an ultrasonic power transfer system through a tightly coupled solid media using a KLM model. Micromachines, 11(4), 355. https:// doi.org/10.3390/MI11040355

Kia, A. G., Ganjloo, A., \& Bimakr, M. (2018). A Short Extraction Time of Polysaccharides from Fenugreek (Trigonella foencem graecum) Seed Using Continuous Ultrasound Acoustic Cavitation: Process Optimization, Characterization and Biological Activities. Food and Bioprocess Technology, 11(12), 2204-2216. https://doi.org/ 10.1007/s11947-018-2178-2

Kumari, B., Tiwari, B. K., Hossain, M. B., Brunton, N. P., \& Rai, D. K. (2018). Recent Advances on Application of Ultrasound and Pulsed Electric Field Technologies in the Extraction of Bioactives from Agro-Industrial By-products. Food and
Bioprocess Technology, 11(2), 223-241. https://doi.org/10. 1007/s11947-017-1961-9

Leone, A., Romaniello, R., Juliano, P., \& Tamborrino, A. (2018). Use of a mixing-coil heat exchanger combined with microwave and ultrasound technology in an olive oil extraction process. Innovative Food Science and Emerging Technologies, 50, 66-72. https://doi.org/10.1016/j.ifset.2018.09.005

Leone, A., Romaniello, R., Zagaria, R., Sabella, E., De Bellis, L., \& Tamborrino, A. (2015). Machining effects of different mechanical crushers on pit particle size and oil drop distribution in olive paste. European Journal of Lipid Science and Technology, 117(8), 1271-1279. https://doi.org/10.1002/ejlt.201400485

Mantas, P., Pagan, R., \& Raso, J. (2000). Predicting Lethal Effect of Ultrasonic Waves Under Pressure Treatments on Listeria monocytogenes ATCC 15313 by Power Measurements. Journal of Food Science, 65(4), 663-667. https://doi.org/10.1111/j.13652621.2000.tb16069.x

Meullemiestre, A., Breil, C., Abert-Vian, M., \& Chemat, F. (2017). Manothermosonication as a useful tool for lipid extraction from oleaginous microorganisms. Ultrasonics Sonochemistry, 37, 216-221. https://doi.org/10.1016/j.ultsonch.2017.01.014

Migliorini, M., Cherubini, C., Mugelli, M., Gianni, G., Trapani, S., \& Zanoni, B. (2011). Relationship between the oil and sugar content in olive oil fruits from Moraiolo and Leccino cultivars during ripening. Scientia Horticulturae, 129(4), 919-921. https:// doi.org/10.1016/j.scienta.2011.05.023

Nergiz, C., \& Engez, Y. (2000). Compositional variation of olive fruit during ripening. Food Chemistry, 69(1), 55-59. https:// doi.org/10.1016/S0308-8146(99)00238-1

Osete-Alcaraz, A., Bautista-Ortín, A. B., Ortega-Regules, A. E., \& Gómez-Plaza, E. (2019). Combined Use of Pectolytic Enzymes and Ultrasounds for Improving the Extraction of Phenolic Compounds During Vinification. Food and Bioprocess Technology, 12(8), 1330-1339. https://doi.org/10.1007/s11947-019-02303-0

Perone, C., Romaniello, R., Leone, A., Catalano, P., \& Tamborrino, A. (2021). CFD Analysis of a Tubular Heat Exchanger for the Conditioning of Olive Paste. Applied Sciences, 11(4), 1858.

Romaniello, R., Tamborrino, A., \& Leone, A. (2019). Use of ultrasound and pulsed electric fields technologies applied to the olive oil extraction process. Chemical Engineering Transactions, 75, 13-18. https://doi.org/10.3303/CET1975003

Sadkaoui, A., Jiménez, A., Aguilera, M. P., Pacheco, R., \& Beltrán, G. (2017). Virgin olive oil yield as affected by physicochemical talc properties and dosage. European Journal of Lipid Science and Technology, 119(1), 1600112. https://doi.org/10.1002/ejlt. 201600112

Saravanakumar, D., Mohan, B., \& Muthuramalingam, T. (2017). A review on recent research trends in servo pneumatic positioning systems. Precision Engineering, 49, 481-492. https://doi.org/ 10.1016/j.precisioneng.2017.01.014

Servili, M., Veneziani, G., Taticchi, A., Romaniello, R., Tamborrino, A., \& Leone, A. (2019). Low-frequency, high-power ultrasound treatment at different pressures for olive paste: Effects on olive oil yield and quality. Ultrasonics Sonochemistry, 59, 104747. https://doi.org/10.1016/j.ultsonch.2019.104747

Steffe, J. F., Mohamed, I. O., \& Ford, E. W. (1984). Pressure Drop Across Valves and Fittings for Pseudoplastic Fluids in Laminar Flow. Transactions of the American Society of Agricultural Engineers, 27(2), 616-619. https://doi.org/10.13031/2013.32838

Tamborrino, A., Catalano, P., \& Leone, A. (2014). Using an in-line rotating torque transducer to study the rheological aspects of malaxed olive paste. Journal of Food Engineering, 126, 65-71. https://doi.org/10.1016/j.jfoodeng.2013.09.024

Tamborrino, A., Romaniello, R., Caponio, F., Squeo, G., \& Leone, A. (2019). Combined industrial olive oil extraction plant using ultrasounds, microwave, and heat exchange: Impact on olive oil 
quality and yield. Journal of Food Engineering, 245, 124-130. https://doi.org/10.1016/j.jfoodeng.2018.10.019

Taticchi, A., Selvaggini, R., Esposto, S., Sordini, B., Veneziani, G., \& Servili, M. (2019). Physicochemical characterization of virgin olive oil obtained using an ultrasound-assisted extraction at an industrial scale: Influence of olive maturity index and malaxation time. Food Chemistry, 289, 7-15. https://doi.org/ 10.1016/j.foodchem.2019.03.041

Tchabo, W., Ma, Y., Kwaw, E., Zhang, H., Li, X., \& Afoakwah, N. A. (2017). Effects of Ultrasound, High Pressure, and
Manosonication Processes on Phenolic Profile and Antioxidant Properties of a Sulfur Dioxide-Free Mulberry (Morus nigra) Wine. Food and Bioprocess Technology, 10(7), 1210-1223. https://doi.org/10.1007/s11947-017-1892-5

Vernès, L., Abert-Vian, M., El Maâtaoui, M., Tao, Y., Bornard, I., \& Chemat, F. (2019). Application of ultrasound for green extraction of proteins from spirulina. Mechanism, optimization, modeling, and industrial prospects. Ultrasonics Sonochemistry, 54, 48-60. https://doi.org/10.1016/j.ultsonch.2019.02.016 